\title{
Perbandingan Keberhasilan Vaginal Birth After a Cesarean (VBAC) pada Inersia Uteri Hipotonik dengan dan tanpa Pemberian Oksitosin Drip
}

\author{
Dani Setiawan, ${ }^{1}$ Sofie Rifayani Krisnadi, ${ }^{2}$ Udin Sabarudin ${ }^{2}$ \\ ${ }^{1}$ Departemen Obstetri dan Ginekologi Rumah Sakit Umum Sumedang, ${ }^{2}$ Departemen Obstetri dan \\ Ginekologi Fakultas Kedokteran-Rumah Sakit Dr. Hasan Sadikin Bandung
}

\begin{abstract}
Abstrak
Percobaan persalinan per vaginam dapat menjadi pilihan untuk wanita yang sebelumnya pernah mengalami seksio sesarea. Percobaan yang berhasil dinamakan sebagai vaginal birth after a cesarean (VBAC). Kegagalan VBAC sering kali disebabkan karena terjadinya inersia uteri hipotonik. Augmentasi oksitosin drip bukan merupakan kontraindikasi, pemberian augmentasi oksitosin drip merupakan upaya untuk meningkatkan angka keberhasilan VBAC akan tetapi harus diberikan dengan pemantauan kontinu. Penelitian ini bertujuan untuk menentukan perbedaan keberhasilan VBAC pada inersia uteri hipotonik dengan dan tanpa pemberian oksitosin drip. Penelitian ini merupakan penelitian eksperimental dengan rancangan uji klinik acak terkontrol (randomized clinical trial), terhadap 40 penderita dengan riwayat seksio sesarea di Rumah Sakit Dr. Hasan Sadikin, Rumah Sakit Umum Daerah Sumedang, dan Rumah Sakit Astana Anyar yang memenuhi kriteria inklusi periode Maret-Mei 2009; dilakukan perbandingan dua kelompok, yaitu kelompok dengan oksitosin drip dan tanpa oksitosin drip. Karakteristik penderita, keberhasilan VBAC, dan komplikasi ibu serta keluaran neonatus dicatat sebagai data. Uji kemaknaan perbedaan dua proporsi dengan menggunakan chi-kuadrat. Hasil penelitian menunjukkan bahwa keberhasilan VBAC secara statistik tidak memperlihatkan perbedaan bermakna antara kelompok oksitosin drip $(80 \%)$ dan tanpa oksitosin drip (60\%) dengan nilai $\mathrm{p}=0,168(\mathrm{p}>0,05)$, tetapi dengan interval kepercayaan $95 \%$ keberhasilan VBAC dengan oksitosin drip lebih besar 1,71 $(0,72-4,06)$. Komplikasi pada ibu dan neonatus yang timbul pada kedua kelompok tidak berbeda bermakna. Simpulan, pemberian oksitosin drip pada kasus inersia uteri hipotonik meningkatkan keberhasilan VBAC. [MKB. 2012;44(2):114-20].
\end{abstract}

Kata kunci: Inersia uteri hipotonik, oksitosin drip, vaginal birth after a cesarean (VBAC)

\section{The Successful Comparison of Vaginal Birth After a Cesarean (VBAC) on Hypotonic Uterine Inertia with and without Oxytocin Infusion}

\begin{abstract}
Trial of labor after cesarean section can be a choice on maternity with cesarean history. The successful trial of labor is then called vaginal birth after a cesarean (VBAC). The failure on VBAC is often caused by hypotonic uterine inertia. Oxytocin infusion augmentation is not a contraindication; it is a solution for increasing success on VBAC with requisite continuing observation. The aim of this research was to determine the successful differences of VBAC on hypotonic uterine inertia with and without oxytocin augmentation. This research was an experimental study on randomized clinical trial, using 40 patients with history of cesarean section at Dr. Hasan Sadikin Hospital and two satellite hospitals (Sumedang and Astana Anyar) during March-May 2009 which fulfilled inclusion criteria divided into two groups; the group using oxytocin infusion and the group without oxytocin infusion. The patients' characteristic, the success on VBAC and the maternal complication also neonatal condition were noted as encode. Chi-square test was used for statistical analysis. There was no statistical significant difference of success between the group used oxytocin infusion $(80 \%)$ and the group without using oxytocin infusion $(60 \%)$ with $p>0.05$ $(\mathrm{p}=0.168)$, but using confidence interval $95 \%$ showed the successful on VBAC with oxytocin infusion was greater $1.71(0.72-4.06)$. The maternity and neonatal complication on two groups did not indicate a significant difference. In conclusion, using oxytocin infusion on hypotonic uterine inertia can increase the success on VBAC. [MKB. 2012;44(2):114-20].
\end{abstract}

Key words: Hypotonic uterine inertia, oxytocin infusion, vaginal birth after a cesarean (VBAC)

Korespondensi: Dani Setiawan, dr., Sp.OG, M.Kes, Departemen Obstetri dan Ginekologi Rumah Sakit Umum Sumedang, jalan Palasari 80 Sumedang 45311, mobile 08112201098, e-mail dr.dani98@gmail.com 


\section{Pendahuluan}

Penanganan wanita yang telah mengalami riwayat seksio sesarea merupakan masalah di bidang obstetri. Sudah berpuluh-puluh tahun wanita yang mempunyai uterus dengan jaringan parut dianggap kontraindikasi untuk melahirkan per vaginam karena kekhawatiran akan terjadinya ruptur uteri. ${ }^{1}$ Angka kejadian seksio sesarea meningkat dalam 20 tahun terakhir ini, akibatnya terjadi peningkatan jumlah wanita dengan riwayat seksio sesarea untuk kehamilan kedua dan menjadi masalah untuk jenis persalinan berikutnya. Pilihan antara tindakan seksio sesarea kembali dan percobaan persalinan per vaginam masing-masing memiliki risiko dan keuntungan tersendiri. ${ }^{1,2}$

Pada tahun 1916, Cragin mengutarakan pendapatnya yang terkenal dan yang sekarang tampak berlebihan once a cesarean, always a caesarean. Dogma ini telah dianut selama $>60$ tahun dengan pertimbangan skar pada uterus akibat seksio sesarea akan menyebabkan jaringan tersebut terlalu lemah untuk berkontraksi selama persalinan., ${ }^{1,2}$

Wanita di Amerika Serikat telah mulai untuk melaksanakan vaginal birth after a cesarean (VBAC) sejak awal tahun 1980. Beberapa tahun kemudian dokter mulai lebih banyak menggunakan insisi transversal segmen rendah (low-transverse incision) untuk seksio sesarea dibandingkan dengan insisi vertikal. ${ }^{2,3}$ Sekarang VBAC semakin memegang peranan penting di bidang obstetri. Hal ini disebabkan persalinan per vaginam dinilai lebih aman untuk ibu maupun bayinya, karena memiliki tingkat morbiditas yang lebih rendah dan biaya yang lebih ringan dibandingkan dengan cara operasi kembali. ${ }^{4}$

Menurut American Congress of Obstetricians and Gynecologists (ACOG) keberhasilan VBAC sekitar 60-80\%. ${ }^{1,2}$ Dari penelitian Anwar dan Gandamihardja ${ }^{5}$ yang dilakukan di Rumah Sakit Dr. Hasan Sadikin (RSHS) Bandung dalam kurun waktu 5 tahun (1991-1995) didapatkan angka keberhasilan persalinan per vaginam pada bekas seksio sesarea $35,9 \%$, sedangkan dari obstetric care record di RSHS selama tahun 2007 keberhasilan persalinan per vaginam pada bekas seksio sesarea hanya sebesar 30\%. Tindakan seksio sesarea ulang terbanyak disebabkan karena inersia uteri hipotonik pada bekas seksio sesarea.

Penelitian ini bertujuan untuk menentukan perbedaan keberhasilan VBAC pada inersia uteri hipotonik dengan dan tanpa pemberian oksitosin drip.

\section{Metode}

Penelitian merupakan penelitian eksperimental dengan rancangan uji klinis acak terkontrol (randomized clinical trial) terhadap 40 penderita dengan riwayat seksio sesarea yang akan melahirkan serta memenuhi kriteria inklusi dan tidak termasuk kriteria eksklusi yang bersedia untuk mengikuti penelitian setelah mendapatkan penjelasan dan menandatangani lembar informed consent, dengan kriteria inklusi: bekas seksio sesarea satu kali, kehamilan tunggal, aterm, presentasi belakang kepala, panggul baik, ketuban $(+)$, inersia uteri hipotonik serta kriteria eksklusi yaitu terdapat kontraindikasi untuk VBAC.

Besar sampel ditentukan berdasarkan formula uji hipotesis dua proporsi didapatkan total sampel 40 orang. Pengambilan sampel diperoleh dari subjek penelitian di kamar bersalin Departemen Obstetri \& Ginekologi RSHS, Rumah Sakit Umum Daerah (RSUD) Sumedang, dan Rumah Sakit Astana Anyar.

Dalam penelitian ini sampel dibagi menjadi 2 kelompok secara acak dengan cara randomisasi memakai cara permutasi blok kemudian penderita yang termasuk kelompok I dilakukan tindakan oksitosin drip sebanyak 1 labu dengan monitoring kontinu. Penanganan penderita yang termasuk kelompok II yaitu tanpa pemberian oksitosin drip masing-masing 20 orang.

Diberikan oksitosin drip 5 unit dalam $500 \mathrm{~mL}$ dekstrose 5\% dengan dosis awal $10 \mathrm{mU} /$ menit (20 tetes), dinaikkan 5 tetes dengan selang waktu 15 menit sampai didapatkan kontraksi uterus yang memadai. Kecepatan maksimum yang diberikan 60 tetes/menit. Dilakukan pengamatan secara kontinu kontraksi rahim, resting tone, dan bunyi jantung anak menggunakan cardiotocography (CTG). Pengelolaan selama kala II sesuai dengan penanganan prosedur tetap Departemen Obstetri dan Ginekologi RSHS.

Analisis data menggunakan uji $\mathrm{X}^{2}$ yaitu untuk menguji perbedaan dua buah proporsi atau untuk membandingkan perbedaan dua kelompok data kualitatif, selain itu digunakan pula uji t untuk membandingkan perbedaan dua rata-rata untuk data kuantitatif berdistribusi normal. Kemaknaan hasil uji ditentukan berdasarkan nilai $\mathrm{p} \leq 0,05$. Semua pengolahan dan analisis data dilakukan dengan menggunakan program SPSS for windows versi 13.0 .

\section{Hasil}

Penelitian ini dilakukan selama periode bulan Maret hingga Mei 2009, selama periode tersebut didapatkan 40 orang subjek penelitian yang memenuhi kriteria inklusi, yaitu terdiri atas 20 subjek dengan pemberian oksitosin drip dan 20 subjek tidak diberikan oksitosin drip. Agar kedua 
Tabel 1 Karakteristik Subjek Kedua Kelompok Penelitian

\begin{tabular}{|c|c|c|c|}
\hline \multirow[t]{2}{*}{ Karakteristik } & $\begin{array}{l}\text { Kelompok I } \\
\text { (Oksitosin Drip) }\end{array}$ & $\begin{array}{c}\text { Kelompok II } \\
\text { (Tanpa Oksitosin Drip) }\end{array}$ & \multirow[t]{2}{*}{ Kemaknaan } \\
\hline & $\mathbf{n}=\mathbf{2 0}$ & $\mathbf{n}=\mathbf{2 0}$ & \\
\hline \multicolumn{4}{|l|}{ Usia ibu (tahun) } \\
\hline $20-35$ & 18 & 20 & $\mathrm{t}=0,935$ \\
\hline$>35$ & 2 & 0 & $\mathrm{p}=0,356$ \\
\hline$X(S D)$ & $30,8(4,4)$ & $29,5(4,0)$ & \\
\hline Rentang & $25-39$ & $23-35$ & \\
\hline \multicolumn{4}{|l|}{ Paritas } \\
\hline 1 & 11 & 14 & \multirow{4}{*}{$\begin{array}{l}x^{2}=2,139 \\
p=0,544\end{array}$} \\
\hline 2 & 9 & 2 & \\
\hline 3 & - & 3 & \\
\hline 4 & - & 1 & \\
\hline \multicolumn{4}{|c|}{ Usia Kehamilan (minggu) } \\
\hline $37-38$ & 4 & 4 & \multirow{7}{*}{$\begin{array}{l}\mathrm{t}=0,699 \\
\mathrm{p}=0,489\end{array}$} \\
\hline $38-39$ & 5 & 3 & \\
\hline $39-40$ & 2 & 4 & \\
\hline $40-41$ & 6 & 4 & \\
\hline $41-42$ & 3 & 2 & \\
\hline $42-43$ & 0 & 3 & \\
\hline $\mathrm{X}(\mathrm{SD})$ & $39,0(1,4)$ & $39,3(1,7)$ & \\
\hline \multicolumn{4}{|c|}{ Jarak seksio sesarea sebelumnya } \\
\hline $\bar{x}(\mathrm{SD})$ & $5,5(2,9)$ & $4,1(1,7)$ & \multirow{3}{*}{$\begin{array}{c}\mathrm{Z}_{\mathrm{M}-\mathrm{W}}=1,403 \\
\mathrm{p}=0,161\end{array}$} \\
\hline Median & 4,8 & 4 & \\
\hline Rentang & $2-13$ & $1,5-8,5$ & \\
\hline \multicolumn{4}{|c|}{ Riwayat persalinan per vaginam sebelumnya } \\
\hline 0 & 11 & 14 & \multirow{4}{*}{$\begin{array}{l}x^{2}=0,56 \\
p=0,327\end{array}$} \\
\hline 1 & 9 & 2 & \\
\hline 2 & 0 & 3 & \\
\hline 3 & 0 & 1 & \\
\hline \multicolumn{4}{|l|}{ BMI $\left(\mathrm{kg} / \mathrm{m}^{2}\right)$} \\
\hline$<19,8$ & 2 & 3 & \multirow{4}{*}{$\begin{array}{l}x^{2}=0,66 \\
p=0,719\end{array}$} \\
\hline $19,8-26$ & 17 & 15 & \\
\hline$>26,0$ & 1 & 2 & \\
\hline $\bar{x}(\mathrm{SD})$ & $25,87(3,23)$ & $25,14(2,34)$ & \\
\hline \multicolumn{4}{|l|}{ Berat lahir (g) } \\
\hline$<3.000$ & 7 & 9 & \multirow{4}{*}{$\begin{array}{l}\mathrm{t}=0,905 \\
\mathrm{p}=0,371\end{array}$} \\
\hline $3.000-3.499$ & 10 & 7 & \\
\hline$\geq 3.500$ & 3 & 4 & \\
\hline $\bar{x}(\mathrm{SD})$ & $3.126(294,4)$ & $3.020,5(430)$ & \\
\hline
\end{tabular}

Keterangan: $\mathrm{t}=$ Uji $\mathrm{t}, \mathrm{X}^{2}=$ uji chi-kuadrat, $\mathrm{Z}_{\mathrm{M}-\mathrm{W}}=$ uji Mann-Whitney

kelompok penelitian dapat diperbandingkan, pada kedua kelompok tersebut dilakukan analisis statistik karakteristik yang meliputi usia ibu, paritas, usia kehamilan, jarak seksio sesarea sebelumnya, berat badan lahir, serta body mass index (BMI).

Usia rata-rata penderita pada kelompok dengan pemberian oksitosin drip 30,8 $(4,4)$ tahun, sedangkan pada kelompok tanpa pemberian oksitosin drip 29,5 $(4,0)$ tahun. Jumlah paritas terbanyak pada kedua kelompok penelitian yaitu paritas 1 (Tabel 1).

Usia kehamilan terbanyak pada penderita kelompok perlakuan oksitosin drip adalah 40 minggu, sedangkan pada kelompok tanpa oksitosin drip 37, 39, dan 40 minggu. Jarak rata- rata antara seksio sesarea sebelumnya dengan persalinan saat ini pada kelompok perlakuan oksitosin drip adalah 5,5 (2,9) tahun, sedangkan pada kelompok tanpa pemberian oksitosin drip $4,1(1,7)$ tahun. Body mass index rata-rata pada kedua kelompok penelitian hampir sama dengan BMI terbanyak $19,8-26,0 \mathrm{~kg} / \mathrm{m}^{2}$.

Berat badan lahir rata-rata pada subjek penelitian kelompok oksitosin drip $3.126(294,4)$ gram, pada kelompok tanpa oksitosin drip 3.020 (430) gram. Hasil uji statistik menunjukkan tidak ada perbedaan bermakna berat badan lahir antara subjek penelitian dengan dan tanpa pemberian oksitosin drip dengan nilai $\mathrm{p}=0,371 \quad(\mathrm{p}>0,05)$ (Tabel 1).

Karakteristik penelitian secara statistik tidak 
Tabel 2 Perbandingan Keberhasilan VBAC pada Inersia Uteri Hipotonik dengan dan tanpa Pemberian Oksitosin Drip

\begin{tabular}{lcccc}
\hline Jenis Persalinan & $\begin{array}{c}\text { Kelompok I } \\
\text { (Pemberian } \\
\text { Oksitosin Drip) }\end{array}$ & $\begin{array}{c}\text { Kelompok II } \\
\text { (Tanpa Oksitosin } \\
\text { Drip) }\end{array}$ & \multirow{2}{*}{$\mathbf{X}^{\mathbf{2}}$} & Kemaknaan \\
\cline { 2 - 4 } Per vaginam & 16 & $\mathbf{n = 2 0}$ & & \\
Spontan & 11 & 11 & & 0,168 \\
Ekstraksi vakum & 5 & 0 & 1,905 & $95 \%$ IK; $0,72-4,06$ \\
Ekstraksi forseps & 0 & 1 & & \\
Seksio sesarea & 4 & 8 & & \\
Total & $\mathbf{2 0}$ & $\mathbf{2 0}$ & &
\end{tabular}

Keterangan: $\mathrm{p}=$ nilai kemaknaan

bermakna, sehingga kedua kelompok dapat dibandingkan.

Jumlah penderita yang berhasil melahirkan per vaginam dengan oksitosin drip lebih besar dibandingkan dengan tanpa pemberian oksitosin drip, tetapi tidak berbeda secara bermakna secara statistik $(\mathrm{p}=0,168)$. Berdasarkan penghitungan menggunakan metode interval kepercayaan $95 \%$ didapatkan keberhasilan persalinan per vaginam pada riwayat seksio sesarea dengan oksitosin drip memiliki keberhasilan lebih besar bila dibandingkan dengan tanpa pemberian oksitosin drip yaitu sebesar 1,71 (0,72-4,06) (Tabel 2).

Hasil uji statistik dengan uji ekstrak Fisher menunjukkan tidak ada perbedaan bermakna antara kedua kelompok perlakuan dari segi komplikasi yang terjadi pada ibu (Tabel 3). Tidak didapatkan kejadian ruptur uteri, histerektomi maupun kematian ibu.

Tidak ada perbedaan bermakna nilai appearance pulse grimace (reflex) activity respiration (APGAR) 1 menit dan 5 menit pada kedua kelompok perlakuan dengan uji chikuadrat. Didapatkan $\mathrm{p}=0,589$ untuk APGAR 1 menit dan $\mathrm{p}=0,819$ untuk APGAR 5 menit.

\section{Pembahasan}

Karakteristik subjek yang dibandingkan pada penelitian ini meliputi usia ibu, paritas, usia kehamilan, jarak seksio sesarea sebelumnya, berat badan lahir, serta BMI. Dari hasil uji t tidak didapatkan hasil yang bermakna $(\mathrm{p}>0,05)$ antara usia ibu $(\mathrm{p}=0,356)$, usia kehamilan $(\mathrm{p}=0,489)$, serta berat badan lahir $(\mathrm{p}=0,371)$. Demikian pula dengan uji chi-kuadrat terhadap paritas $(\mathrm{p}=0,544)$ serta BMI $(p=0,719)$, sehingga kedua kelompok selanjutnya dapat dibandingkan.

Wanita dengan usia lebih tua dari 40 tahun memiliki risiko kegagalan 3 sampai 4 kali lebih tinggi pada percobaan partus per vaginam dibandingkan dengan wanita yang berusia kurang dari 40 tahun. ${ }^{6}$ Keberhasilan VBAC sebesar 2,58 kali lebih tinggi pada wanita di bawah usia 40 tahun dibandingkan dengan 40 tahun atau lebih. ${ }^{7}$

Insidensi ruptur uteri pada wanita $<30$ tahun dengan wanita $\geq 30$ tahun berbeda yaitu $0,5 \%$ dan $1,4 \%$. Pada penelitian ini usia penderita terbanyak pada kedua kelompok penelitian kurang dari 35 tahun dan hanya 2 orang penderita dengan usia lebih dari 35 tahun.

Menurut Landon dkk. ${ }^{8,9}$ wanita yang pendek dan obes cenderung untuk mengalami kegagalan. Pada penelitian Juhasz dkk. ${ }^{10}$ dinyatakan bahwa kondisi obesitas pada penderita menurunkan angka keberhasilan VBAC. Secara keseluruhan kesuksesan VBAC sebesar 77,2\%. Untuk BMI $<19,8$ keberhasilan sebesar $83,1 \%$; BMI 19,8 26 keberhasilan VBAC 79,9\%; BMI 26,1-29

Tabel 3 Perbandingan Keluaran Neonatus

\begin{tabular}{|c|c|c|c|c|c|}
\hline \multicolumn{2}{|c|}{$\begin{array}{l}\text { Keluaran } \\
\text { Neonatus }\end{array}$} & \multirow{2}{*}{$\begin{array}{c}\text { Kelompok I } \\
\text { (Pemberian Oksitosin Drip) } \\
1\end{array}$} & \multirow{2}{*}{$\begin{array}{c}\text { Kelompok II } \\
\text { (Tanpa Oksitosin Drip) } \\
0\end{array}$} & \multirow[t]{2}{*}{$\chi^{2}$} & \multirow[t]{2}{*}{ Kemaknaan } \\
\hline APGAR & 6 & & & & \\
\hline 1 menit & 7 & 11 & 11 & 1,059 & 0,589 \\
\hline & $\begin{array}{l}8 \\
8\end{array}$ & $\begin{array}{l}8 \\
1\end{array}$ & $\begin{array}{l}9 \\
2\end{array}$ & & \\
\hline APGAR & 9 & 11 & 11 & & \\
\hline 5 menit & 10 & 8 & 7 & 0,400 & 0,819 \\
\hline Kematiar & rinatal & 0 & 0 & & \\
\hline
\end{tabular}

Keterangan: $\mathrm{X}^{2}=$ uji chi-kuadrat 
keberhasilan 69,3\%; dan BMI $>29$ keberhasilan $68,2 \%$, dengan nilai $\mathrm{p}<0,001$.

Keberhasilan VBAC paling banyak pada usia kehamilan antara 37 sampai dengan 40 minggu, sedangkan usia kehamilan $>41$ minggu keberhasilan VBAC lebih rendah, hal ini sejalan dengan penelitian Coassolo dkk. ${ }^{11}$ bahwa tingkat kesuksesan akan lebih rendah pada usia kehamilan di atas 40 minggu.

Sebagian besar kasus bekas seksio sesarea pada penelitian ini berjarak 4-5 tahun dari seksio sesarea sebelumnya. Interval waktu antara VBAC dan seksio sesarea sebelumnya pada penelitian ini terdekat 20 bulan dan terlama 13 tahun. Huang dkk. ${ }^{12}$ mendapatkan angka keberhasilan persalinan per vaginam sebesar $79 \%$ pada kasus dengan jarak persalinan kurang dari 19 bulan, sedangkan dengan jarak persalinan lebih dari 19 bulan, angka keberhasilannya mencapai $85,5 \%$. Pada penelitian ini tidak didapatkan ruptur uteri. Angka ruptur uteri meningkat tiga kali pada kehamilan kurang dari 6 bulan setelah seksio sesarea.

Stamilio dkk. ${ }^{13}$ mempelajari pengaruh jarak kehamilan dengan seksio sesarea sebelumnya, pada jarak kehamilan kurang dari 6 bulan risiko ruptur uteri sebesar 2,7\%; morbiditas ibu meningkat menjadi $4,2 \%$ serta kebutuhan untuk transfusi meningkat menjadi 2,4\%. Pada kehamilan dengan jarak 6-18 bulan risiko untuk ruptur uteri sebesar $0,9 \%$; morbiditas ibu 2,2\% dan kebutuhan transfusi $0,7 \%$; sedangkan untuk jarak kehamilan kurang dari 5 tahun risiko ruptur $1 \%$, morbiditas ibu 2,2\%; transfusi $0,6 \%$. Pada jarak kehamilan lebih lama yaitu lebih dari 5 tahun risiko ruptur $0,9 \%$; morbiditas ibu 2,2; serta kebutuhan transfusi $1 \%$.

Kesuksesan persalinan per vaginam setelah seksio sesarea bagi penderita dengan riwayat persalinan spontan sebelumnya lebih tinggi bila dibandingkan dengan yang belum pernah persalinan per vaginam, akan tetapi pada penelitian ini tampak bahwa penderita tanpa riwayat persalinan per vaginam pun keberhasilan VBAC cukup tinggi.

Caughey dan Spandorfer ${ }^{14}$ mendapat hasil bahwa penderita yang pernah melahirkan per vaginam memiliki angka seksio sesarea yang lebih rendah bila dibandingkan dengan penderita yang tidak pernah melahirkan per vaginam. Hal yang sama dilaporkan pula oleh Flamm dkk..$^{15}$

Selain itu, Caughey dan Spandorfer ${ }^{14}$ juga mendapatkan bahwa bila persalinan per vaginam terjadi setelah riwayat seksio sesarea terdahulu, angka keberhasilan persalinan per vaginam akan lebih tinggi $(92,8 \%)$ dibandingkan dengan persalinan tersebut terjadi sebelum riwayat seksio sesarea terdahulu $(85,5 \%)$.
Berat badan bayi $>4.000$ gram berhubungan dengan penurunan angka keberhasilan VBAC (55-67\%). Elkousy dan Mohammed ${ }^{16}$ telah mengevaluasi efek peningkatan berat badan lahir untuk wanita yang menjalani percobaan persalinan per vaginam. Dilakukan analisis pada wanita tanpa riwayat persalinan per vaginam sebelumnya dengan berat bayi $<4.000$ g, 4.000-4.249 g, 4.250-4.500 g, dan $>4.500 \mathrm{~g}$ didapatkan hasil penurunan keberhasilan VBAC berturut-turut $68 \%, 52 \%, 45 \%$, dan $38 \%$. Wanita dengan janin makrosomia dan riwayat persalinan per vaginam harus diinformasikan mengenai kemungkinan keberhasilan persalinan per vaginam. Keberhasilan VBAC pada bayi dengan berat lebih dari 4.000 gram $<50 \%$.

Penelitian yang dilakukan oleh Flamm dkk. ${ }^{15}$ menemukan bahwa tingkat keberhasilan partus per vaginam pada bekas seksio sesarea sebesar $75 \%$ dengan risiko terjadinya ruptur uteri kurang dari $1 \%$, hasil ini sesuai dengan keberhasilan persalinan pada kelompok yang dilakukan tindakan oksitosin drip yang mencapai $80 \%$ tetapi lebih rendah pada kelompok tanpa diberikan oksitosin drip yaitu sebesar $60 \%$.

Flamm dkk. ${ }^{15}$ menyatakan bahwa penipisan serta dilatasi serviks memperbesar keberhasilan persalinan per vaginam pada bekas seksio sesarea. Pembukaan serviks saat datang berpengaruh pada keberhasilan VBAC, penderita yang saat datang pembukaan serviks lebih atau sama dengan 3 $\mathrm{cm}$ mempunyai keberhasilan persalinan spontan yang lebih besar. Flamm dkk. ${ }^{15}$ menyatakan pembukaan serviks lebih atau sama dengan $4 \mathrm{~cm}$ mempunyai keberhasilan $86 \%$.

Pembukaan serviks saat datang termasuk ke dalam sistem skoring Flamm dkk. ${ }^{15}$ Sistem skoring Flamm dkk. ${ }^{15}$ digunakan saat penderita masuk rumah sakit untuk persalinan. Menurut Flamm dkk. ${ }^{15}$ skor 0-2 kemungkinan keberhasilan $49 \%$, sedangkan skor tinggi 8-10 kemungkinan keberhasilan 95\%.

Pada penelitian ini berdasarkan hasil analisis statistik chi-kuadrat tidak berbeda bermakna $(p>0,05)$ antara pembukaan saat datang $(p=0,517)$ pada kedua kelompok penelitian. Pada kedua kelompok pembukaan saat datang terbanyak pada pembukaan serviks $3 \mathrm{~cm}$.

Keberhasilan VBAC bila dilihat dari indikasi seksio sesarea sebelumnya pada penelitian ini tampaknya tidak berhubungan bermakna. Tingkat kesuksesan rata-rata tinggi ditemukan pada wanita dengan seksio sesarea sebelumnya yang dilakukan karena presentasi sungsang dan pada persalinan per vaginam berikutnya yang telah terjadi. Wanita dengan riwayat persalinan seksio sesarea karena cephalo-pelvic disproportion (CPD) menunjukkan tingkat kesuksesan terendah 
untuk VBAC. Gawat janin memiliki keberhasilan VBAC terendah kedua yaitu $69-73 \%$.

Indikasi terbanyak pada seksio sesarea terdahulu pada penelitian ini yaitu oksitosin drip gagal, kemudian gawat janin dan plasenta previa, sedangkan dalam jumlah yang lebih kecil tali pusat menumbung, impending eklamsi, dan kelainan letak.

Risiko ruptur uteri dan keluaran janin yang buruk untuk wanita dengan kehamilan aterm, tunggal dengan riwayat bekas seksio sesarea rendah yaitu 3 dari 1.000 kasus. Konseling untuk wanita dengan riwayat seksio sesarea untuk terjadinya ruptur uteri $0-0,74 \% .{ }^{17}$ Beberapa penulis melaporkan tidak ditemukan peningkatan bermakna kejadian yang membahayakan saat dilakukan percobaan persalinan pada kasus yang jenis insisinya tidak diketahui, dan bila terjadi ruptur uteri hal itu berhubungan dengan jenis insisi vertikal. Hal ini mungkin disebabkan karena saat ini diketahui bahwa 90-95\% jenis insisi parut uterus yang tidak diketahui yaitu seksio sesarea transperitonealis profunda.

Morbiditas maternal menunjukkan 19,7\% insidensi demam/infeksi lebih tinggi pada wanita yang menjalankan seksio sesarea ulangan dibandingkan dengan $11,7 \%$ wanita yang melakukan persalinan per vaginam. Perbedaan yang jelas bahwa persalinan per vaginam menyebabkan lama perawatan lebih singkat, transfusi dan terjadinya febris pascasalin yang lebih rendah. ${ }^{18}$ Menurut Flamm dkk. ${ }^{15}$ seksio sesarea berulang menunjukkan peningkatan angka kejadian lamanya perawatan di rumah sakit $(84,9$ jam vs 57,2 jam; $p=0,0001)$ dan peningkatan frekuensi transfusi darah $(1,72 \%$ vs $0,72 \% ; p=0,0001)$ tetapi terdapat penurunan insidensi skor APGAR $<7$ pada 5 menit pertama $(0,68 \%$ vs $1.48 \%$; $p=0,004) .{ }^{18}$ Pada penelitian ini tidak terdapat perbedaan bermakna morbiditas maternal maupun perinatal pada penderita yang mendapat oksitosin dibandingkan dengan yang tidak mendapat oksitosin, juga tidak terdapat perbedaan insidensi ruptur uteri antara kedua kelompok tersebut. Pada penelitian ini seksio sesarea berulang menunjukkan peningkatan lamanya perawatan di rumah sakit (96 jam vs 48 jam), tetapi tidak meningkatkan frekuensi transfusi darah. Skor APGAR tidak berbeda bermakna antara tindakan seksio sesarea ulang dan persalinan per vaginam.

Pemberian oksitosin secara luas digunakan untuk induksi atau augmentasi persalinan. Pendapat para ahli obstetri saat ini terdapat riwayat seksio sesarea bukan merupakan kontraindikasi penggunaan oksitosin untuk induksi atau augmentasi pada saat persalinan; oksitosin dapat digunakan secara efektif dengan tanpa peningkatan risiko terhadap ibu maupun janin. ${ }^{2,19}$

Penelitian mengenai keamanan penggunaan oksitosin pada VBAC telah banyak dipublikasikan, pada beberapa penelitian dinyatakan bahwa risiko ruptur meningkat tetapi dari penelitian lain tidak didapatkan hubungan.

Beberapa penelitian melaporkan keberhasilan persalinan per vaginam pada bekas seksio sesarea dengan pemberian oksitosin, ternyata tidak terdapat peningkatan risiko baik untuk ibu maupun anak dibandingkan dengan tanpa penggunaan oksitosin. Mereka berkesimpulan bahwa penggunaan oksitosin pada bekas seksio sesarea aman bila dilakukan dengan pemantauan yang cermat. ${ }^{15,19}$ Goetzl dkk. ${ }^{20}$ memeriksa hubungan antara dosis oksitosin yang dapat digunakan dengan risiko ruptur uteri, ternyata tidak didapatkan hubungan bermakna antara pemberian oksitosin dan risiko ruptur uteri. ${ }^{20}$

Flamm dkk. ${ }^{15}$ meneliti 7.299 wanita dengan riwayat persalinan seksio sesarea dan dilaporkan hasilnya rata-rata $75 \%$ setuju untuk dilakukan VBAC serta menerima pemberian oksitosin baik sebagai induksi atau augmentasi pada saat persalinan. Tidak terdapat perbedaan bermakna morbiditas maternal maupun perinatal pada penderita yang mendapat oksitosin dibandingkan dengan yang tidak mendapat oksitosin serta tidak terdapat perbedaan juga pada insidensi ruptur uteri. ${ }^{16,20}$

Pada penelitian ini untuk menggambarkan keadaan anak yang dilahirkan baik per vaginam maupun per abdominal dengan menggunakan skor APGAR. Penelitian lain mendapatkan skor APGAR 5 menit kurang dari 7 pada percobaan persalinan per vaginam $1,47 \%$.

Simpulan, pemberian oksitosin drip pada inersia hipotonik meningkatkan keberhasilan VBAC.

\section{Daftar Pustaka}

1. Cunningham FG, Bloom SL, Leveno KJ, Gilstrap LC, Hauth JC, Wenstrom KD. William's obstetrics. Edisi ke-22. London: McGraw Hill; 2005.

2. Smith CS. Delivery after previous cesarean section. Dalam: James D, Steer PJ, Weiner CP, Gonik B, penyunting. High risk pregnancy. Edisi ke-3. New York: WB Saunders; 2006. hlm. 2193-206.

3. Hendler I, Bujould E. Effect of prior vaginal delivery or prior vaginal birth after cesarean delivery on obstetrics outcome in women undergoing trial of labor. Am J Obstet Gynecol. 2004;104:273-7. 
4. Dodd JM, Crowther CA. Elective repeat cesarean section versus induction of labor for women with a previous cesarean birth. The Cochrane Collaboration. The Cochrane Library; 2007.

5. Anwar R, Gandamihardja S. Tinjauan persalinan per vaginam pada bekas seksio sesaria di RS Hasan Sadikin Bandung selama 5 tahun (1991-1995). Bandung: Bagian Obstetri Ginekologi FK Unpad; 1995.

6. Cahill AG, Stamilio DM, Odibo AO. Is vaginal birth after cesarean (VBAC) or elective repeat cesarean safer in women with a prior vaginal delivery? Am J Obstet Gynecol. 2006; 195:1143-7.

7. Royal College of Obstetricians and Gynaecologist. Birth after previous caesarean birth. Green-top Guideline. 2007: $1-100$.

8. Landon MB, Hauth JC, Leveno KJ, Spong CY, Leindecker S, Varner MW, dkk. Maternal and perinatal outcomes associated with a trial of labor after prior cesarean delivery. N Engl J Med. 2004;351(25):2581-9.

9. Landon MB, Leindecker S, Spong CY, Hauth JC, Bloom S, Varner MW. The MFMU cesarean registry: factors affecting the success of trial of labor after previous cesarean delivery. Am J Obstet Gynecol. 2005; 193:1016-23.

10. Juhasz G, Gyamfi C, Tocce K. Effect of body mass index and excessive weight gain on success of vaginal birth after cesarean delivery. Obstet Gynecol. 2005;106:741-6.

11. Coassolo KM, Stamilio SM, Pare E. Safety and efficacy of vaginal birth after cesarean attempts at or beyond 40 weeks of gestations. Am J Obstet Gynecol. 2005;106:700-6.

12. Huang WH, Nakashima DK, Rumney PJ, Keegan KA, Chan K. Interdelivery interval and the success of vaginal birth after cesarean delivery. Obstet Gynecol. 2002;99(1):41-4.

13. Stamilio DM, Cahill AG, Waterman BM. Higher maximum doses of oxytocin are associated with an unacceptably high risk for uterine rupture in patients attempting vaginal birth after cesarean delivery. Am J Obstet Gynecol. 2008;199:32.

14. Caughey AB, Spandorfer SD. Vaginal birth after cesarean delivery. Clin Obstet Gynecol. 2008;101:1-5.

15. Flamm BL, Lim OW, Jones C, Fallon D, Newman LA, Mantis JK. Vaginal birth after cesarean section: results of multicenter study. Am J Obstet Gynecol. 1998;158:1079-84.

16. Elkousy MA, Mohammed A. The effect of birth weight on vaginal birth after cesarean delivery success rate. Obstet Gynecol. 2003;188:824-30.

17. Macones GA, Grobman WA, Lai Y, Landon MB. Prediction of uterine rupture assosiated with attempted vaginal birth after cesarean delivery. Am J Obstet Gynecol. 2008;1(199):30-1.

18. Wen SW, Rusen ID, Walker M, Liston R, Kramer MS, Baskett T, dkk. Comparison of maternal mortality and morbidity between trial of labor and elective cesarean section among women with previous cesarean delivery. Am J Obstet Gynecol. 2004;191(4):12363-9.

19. Chua S, Arulkumaran S. Poor progres in labor including augmentation. Dalam: James DK, Steer PJ, Weiner CP, Gonik B, penyunting. High risk pregnancy. Edisi ke3. Philadelphia: WB Saunders; 2006. hlm. 1106-8.

20. Goetzl L, Shipp TA, Cohen A, Zelop CM, Repke JT, Lieberman E. Oxytocin dose and the risk of uterine rupture in trial of labor after cesarean. Obstet Gynecol. 2001;97:381-4. 


\title{
Uji Validitas Neutrophil Gelatinase Associated Lipocalin sebagai Penanda Diagnosis Gangguan Ginjal Akut pada Sepsis
}

\author{
Hidayat, ${ }^{1}$ Ida Parwati, ${ }^{1}$ Rubin Surachno Gondodiputro, ${ }^{2}$ Coriejati Rita ${ }^{1}$ \\ ${ }^{1}$ Laboratorium Patologi Klinik Rumah Sakit Dr. H. Abdul Moeloek Lampung , ${ }^{2}$ Departemen Ilmu \\ Penyakit Dalam Fakultas Kedokteran Universitas Padjadjaran-Rumah Sakit Dr. Hasan Sadikin \\ Bandung
}

\begin{abstract}
Abstrak
Gangguan ginjal akut (GgGA) merupakan penurunan fungsi ginjal secara mendadak yang ditandai dengan peningkatan kreatinin serum $\geq 0,3 \mathrm{mg} / \mathrm{dL}$ atau meningkat $>1,5$ kali dari kadar sebelumnya atau penurunan urine output $(\mathrm{UO})<0,5 \mathrm{~mL}$ per jam selama $>6$ jam. Sepsis merupakan penyebab tersering GgGA dengan angka kejadian berkisar 20-50\% dan angka kematian mendekati 70\%. Kadar neutrophil gelatinase associated lipocalin (NGAL) urine penderita GgGA dapat meningkat secara cepat dan lebih awal dibandingkan dengan kadar kreatinin serum sehingga NGAL dapat dijadikan penanda diagnosis GgGA. Penelitian bertujuan mengetahui validitas NGAL urine sebagai penanda diagnosis GgGA pada penderita sepsis. Sebanyak 50 sampel urine diambil dari penderita sepsis di Unit Gawat Darurat (UGD), Intensive Care Unit (ICU), dan Medical Intermediate Care (MIC) di Rumah Sakit Dr. Hasan Sadikin Bandung selama Februari sampai Mei 2010 dan dilakukan pemeriksaan kadar NGAL urine dengan metode enzyme linked immunosorbent assay (ELISA). Data yang diperoleh dianalisis dengan uji nonparametrik Mann-Whitney, kurva receiver operating characteristic (ROC), dan uji validitas. Hasil penelitian didapatkan kadar NGAL urine penderita sepsis dengan GgGA lebih tinggi secara bermakna dibandingkan dengan penderita sepsis tanpa GgGA (3.380 ng/mL berbanding $116 \mathrm{ng} / \mathrm{mL} ; \mathrm{p}<0,001)$. Pada cut-off point $107 \mathrm{ng} / \mathrm{mL}$, NGAL urine memiliki sensitivitas $100 \%$, spesifisitas $36 \%$, positive predictive value (PPV) $60,9 \%$, negative predictive value (NPV) $100 \%$, dan akurasi $68 \%$. Simpulan, kadar NGAL urine memiliki validitas yang baik dan dapat dijadikan sebagai penanda diagnosis terjadinya GgGA pada penderita sepsis. [MKB. 2012;44(2):121-6].
\end{abstract}

Kata kunci: Gangguan ginjal akut, kreatinin, neutrophil gelatinase associated lipocalin, penanda diagnosis, sepsis

\section{Validity Test of Neutrophil Gelatinase Associated Lipocalin as Diagnostic Marker forAcute Kidney Injury on Sepsis}

\begin{abstract}
Acute kidney injury (AKI) is an abrupt decrease of renal function which marked by increase of serum creatinine $\geq 0.3 \mathrm{mg} / \mathrm{dL}$ or $\geq 1.5$ times of previous level or decrease urine output $<0.5 \mathrm{~mL} /$ hour in $>6$ hours. Sepsis is the most common cause of AKI with incidence rate is about $20-50 \%$ and mortality nearly $70 \%$. Urine neutrophil gelatinaseassociated lipocalin (NGAL) level in AKI patients can increase quickly and earlier compared with serum creatinine and could be as a marker for AKI. The purpose of this study was to assess the validity of urine NGAL as diagnostic marker of AKI on sepsis patients. Subjects were 50 urine samples of sepsis patients from Emergency Department (ED), Intensive Care Unit (ICU) and Medical Intermediate Care (MIC) in Dr. Hasan Sadikin Hospital Bandung between February and May 2010 and were examined with enzyme linked immunosorbent assay (ELISA) method. Data analysis was performed by non parametric Mann-Whitney test, receiver operating characteristic (ROC) analysis and validity test. The results found that urine NGAL of AKI patients were significantly higher compared with non AKI patients $(3,380 \mathrm{ng} / \mathrm{mL}$ vs $116 \mathrm{ng} / \mathrm{mL}, \mathrm{p}<0.001)$. A cut-off point $>107 \mathrm{ng} / \mathrm{mL}$ for urine NGAL had a sensitivity of $100 \%$, specificity of $36 \%$, positive predictive value (PPV) of $60.9 \%$, negative predictive value (NPV) of $100 \%$ and accuracy of $68 \%$. In conclusions, urinary NGAL level has good validity and could be used as a screening test for AKI on sepsis patients. [MKB. 2012;44(2):121-6].
\end{abstract}

Key words: Acute kidney injury (AKI), creatinine, diagnostic marker, neutrophil gelatinase associated lipocalin, sepsis

Korespondensi: Hidayat, dr., Sp.PK, Laboratorium Patologi Klinik Rumah Sakit Dr. H. Abdul Moeloek Lampung, jalan Dr. Rivai 6 Bandar Lampung, mobile 081368250177, e-mail hidayatpatklin2007@yahoo.com 